\title{
The comparison of depression, sleepiness and depression severity between patients with primary snoring and patients with obstructive sleep apnea
}

\author{
Basit horlaması olan hastalar ve tıkayıcı uyku apnesi olan hastalar arasinda depresyon, \\ uykululuk ve depresyon şiddetinin karşılaştırılması
}

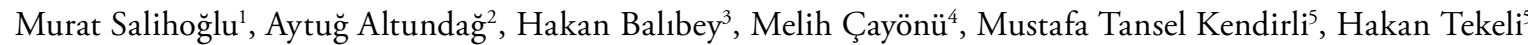 \\ ${ }^{1}$ Department of Otolaryngology, GATA Haydarpaşa Training Hospital, İstanbul, Turkey \\ ${ }^{2}$ Division of Otorhinolaryngology, Istanbul Surgery Hospital, İstanbul, Turkey \\ ${ }^{3}$ Department of Psychiatry, GATA Haydarpaşa Training Hospital, İstanbul, Turkey \\ ${ }^{4}$ Department of Otorhinolaryngology, Amasya University Training and Research Hospital, Amasya, Turkey \\ ${ }^{5}$ Department of Neurology, GATA Haydarpaşa Training Hospital, İstanbul, Turkey
}

\begin{abstract}
Objectives: This study aims to investigate the relationship between the frequency of depression symptoms, severity of obstructive sleep apnea (OSA), sleepiness score, and depression symptoms in patients with primary snoring and patients with OSA.

Patients and Methods: This study was carried out with 105 volunteers (93 males, 12 females; mean age $47 \pm 13.2$ years; range 20 to 78 years) between January 2010 and June 2013 in our clinic. Physical examination, Epworth sleepiness scale, and Beck depression inventory were applied. Age and sex matched patients were divided into four groups: (i) control group with primary snoring, (ii) mild OSA group (iii) moderate OSA group, and (iv) severe OSA group.
\end{abstract}

Results: This study produced four major findings: (i) Apneahypopnea index was not significantly correlated with Beck depression inventory score, Epworth sleepiness scale score, and body mass index. (ii) There was a significant difference between study groups in terms of the prevalence of depression. Mild to moderate depression was more common in OSA patients than patients with primary snoring. (iii) Beck depression inventory score had no significant correlation with Epworth sleepiness scale score and body mass index. (iv) There was no significant difference between study groups in terms of excessive daytime sleepiness.

Conclusion: Although no correlation was present between apnea-hyponea index and Beck depression inventory, mild to moderate depression was more common in OSA patients compared to patients with primary snoring.

Keywords: Beck depression inventory; depression; Epworth sleepiness scale; obstructive sleep apnea.
Amaç: Bu çalışmada basit horlaması olan hastalar ve tıkayıcı uyku apnesi (TUA) olan hastalarda depresyon semptomlarının sıklığı, TUA şiddeti, uykululuk skoru ve depresyon semptomları arasındaki ilişki araştırıldı.

Hastalar ve Yöntemler: Çalışma Ocak 2010 - Haziran 2013 tarihleri arasında 105 gönüllü (93 erkek, 12 kadın; ort. yaş $47 \pm 13.2$ yıl; dağılım $20-78$ yıl) ile kliniğimizde yapıldı. Fizik muayene, Epworth Uykululuk Skalası ve Beck Depresyon Sayımı uygulandı. Yaş ve cinsiyet olarak eşleştirilmiş hastalar dört gruba ayrıldı: (i) basit horlaması olan kontrol grubu, (ii) hafif TUA grubu, (iii) orta TUA grubu ve (iv) şiddetli TUA grubu.

Bulgular: $\mathrm{Bu}$ çalışmada başlıca dört ana sonuca ulaşıldı: (i) Apne-hipopne indeksi ile Beck Depresyon Sayımı skoru, Epworth Uykululuk Skalası skoru ve vücut kütle indeksi arasında anlamlı bir ilişki yoktu. (ii) Depresyon prevalansı açısından çalışma grupları arasında anlamlı bir farklılık vardı. Hafif ila orta dereceli depresyon, TUA hastalarında basit horlaması olan hastalardan daha yaygındı. (iii) Beck Depresyon Sayımı skoru, Epworth Uykululuk Skalası skoru ve vücut kütle indeksi ile anlamlı ilişkiye sahip değildi. (iv) Gündüz aşırı uykululuk açısından çalışma grupları arasında anlamlı bir farklılık yoktu.

Sonuç: Apne-hipopne indeksi ve Beck Depresyon Sayımı arasında ilişki olmamasına rağmen, TUA hastalarında basit horlaması olan hastalara kıyasla hafif ila orta dereceli depresyon daha yaygind.

Anahtar sözcükler: Beck depresyon sayımı; depresyon; Epworth uykululuk skalası; tıkayıcı uyku apnesi. 
It is well known that obstructive sleep apnea (OSA) is characterized by breathing cessation (apnea) or reduction of airflow (hypopnea) during sleep, heavy snoring and excessive daytime sleepiness (EDS). ${ }^{[1-3]}$ Obstructive sleep apnea is a disease affecting about 2 to $4 \%$ of the adult population and is more commonly recognized nowadays because of its significant negative effects including increased risk of cardiovascular and cerebrovascular mortality and morbidity ${ }^{[3-6]}$ It is also known that OSA is associated with neurocognitive and psychological problems affecting memory and new learning, attention, executive function and may be related to depression. ${ }^{[7-10]}$

The relationship between OSA and depression is uncertain. ${ }^{[11-13]}$ Some studies report an increase in depression score with increasing severity of OSA, suggesting the possibility of a causal relationship. ${ }^{[14-17]} \mathrm{On}$ the other hand, others have found no such relationship between disease severity and depressive symptoms in mild to moderate OSA patients and primary snorers. ${ }^{[13,18,19]}$ The high prevalence of OSA and depression in the general population emphasizes the need for a clear insight of the relationship between the two conditions.

Therefore, the objective of this study was to determine the frequency of depressive symptoms in patients with habitual snoring and OSA in Turkey. This study also aimed to investigate the relationship between severity of OSA, sleepiness scores and the presence of depressive symptoms.

\section{PATIENTS AND METHODS}

We conducted this clinical study between the years January 2010 and June 2013 at the Neurology, Psychiatry and Otorhinolaryngology Departments of GATA Haydarpaşa Training Hospital. All investigations were performed in accordance with the declaration of Helsinki on biomedical studies involving human subjects and informed consent was obtained from all study subjects. This study was approved by the Ethics Committee of GATA Haydarpaşa Training Hospital (2013-85).

This study was carried out among 105 volunteers (93 males and 12 females) between the ages of 20-78 years. The mean age of the patients was $47 \pm 13.2$ years. Age and sex matched patients were divided into four groups according to polysomnography (PSG) results as described above: (i) primary snorers as control group, (ii) mild OSA group (iii) moderate OSA group and (iv) severe OSA group. Participants were selected from patients who presented with a clinical suspicion of OSA and were admitted to the sleep lab of GATA Haydarpaşa
Training Hospital. Prior to the onset of the sleep study, data were registered for each subject individually, including height and weight in order to calculate body mass index (BMI), medical history, tobacco use and medication list. Patients who underwent sleep surgery or were currently using continuous positive airway pressure (CPAP) were not included in the study. Patients with major cardiovascular or psychiatric disorders were not included in the study either. Age and sex matched four groups were constituted according to the sleep lab study results. The Epworth sleepiness scale (ESS) is the most widely used selfreport questionnaire to assess EDS, particularly in OSA patients. ${ }^{[20]}$ A validated Turkish version of the ESS questionnaire was completed [eight items with four point, scale (0-3)] as previously described for every participant included in the study prior to the diagnostic sleep study. ${ }^{[21]}$ The ESS score ranged from 0 to 24, with higher scores indicating more sleepiness. Excessive daytime sleepiness was considered present when the ESS score was $>10$, and those with an ESS score of $\leq 10$ were considered to have no EDS.

All participants completed a measure of current level of depression and mood prior to their diagnostic sleep study. A validated Turkish version of the Beck depression inventory (BDI), a 21-item self report inventory for assessing current levels of depression, was used. ${ }^{[22]}$ It is based on a series of key aspects of behavior and emotion in which the respondent rates items on a four-point scale (0-3) with a potential range of total scores from 0 to 63 . According to Beck, the following cutoff points have been proposed: 0 to 13 means minimum or nonexistent depression; 14 to 19 , mild depression; 20 to 28, moderate depression; and 29 or more, severe depression. ${ }^{[23]}$

Polysomnography is the gold standard assessment method for OSA. ${ }^{[3,11,24]}$ All the participants underwent a full night PSG study with at least seven hours of recording time (Astro-Med Inc ${ }^{\circledR}$, Grass Technologies, Model AURA PSG Base, Software Grass Database Explorer Version 4.5.3.23, West Warmick, RI-USA). Sleep staging was scored according to the criteria of American Academy of Sleep Medicine (AASM) published in 2009. ${ }^{[3]}$ Apnea was defined as cessation of airflow for $\geq 10$ seconds. Hypopnea was defined as a $\geq 30 \%$ reduction of airflow, lasting $\geq 10$ seconds, and associated with a $\geq 4 \%$ decrease in oxyhemoglobin saturation (or followed by an arousal when OSA was diagnosed overnight PSG). The number of apneas and hypopneas per hour of sleep were calculated to obtain the apnea-hypopnea index (AHI). The participants were classified into four different groups according to the diagnostic criteria for OSA based on the AASM 


\begin{tabular}{|c|c|c|c|c|c|c|c|c|c|}
\hline \multicolumn{10}{|c|}{$\begin{array}{l}\text { Descriptive statistics of results from sleep lab study, Beck depression inventory and Epworth sleepiness scale according } \\
\text { to the groups }(\mathrm{n}=105)\end{array}$} \\
\hline \multirow{2}{*}{ Variables } & \multicolumn{2}{|c|}{ Primary snoring } & \multicolumn{2}{|c|}{ Mild OSA } & \multicolumn{2}{|c|}{ Moderate OSA } & \multicolumn{2}{|c|}{ Severe OSA } & \multirow[b]{2}{*}{$p$} \\
\hline & $\mathrm{n}$ & Mean \pm SD & $\mathrm{n}$ & Mean \pm SD & $\mathrm{n}$ & Mean $\pm S D$ & $\overline{\mathrm{n}}$ & Mean \pm SD & \\
\hline Age & & $44.5 \pm 9.7$ & & $47.8 \pm 10.3$ & & $45.4 \pm 10.5$ & & $45.2 \pm 9.4$ & 0.54 \\
\hline \multicolumn{10}{|l|}{ Gender } \\
\hline Female & 2 & & 4 & & 3 & & 3 & & \multirow{2}{*}{0.8} \\
\hline Male & 10 & & 29 & & 30 & & 24 & & \\
\hline BMI $\left(\mathrm{kg} / \mathrm{m}^{2}\right)$ & & $27.6 \pm 4.9$ & & $30.2 \pm 5.7$ & & $29.4 \pm 4.6$ & & $31.3 \pm 5.3$ & 0.13 \\
\hline ESS score & & $8.3 \pm 3.8$ & & $9.1 \pm 4.3$ & & $8.7 \pm 4.2$ & & $9.3 \pm 5.7$ & 0.8 \\
\hline AHI (events/hour) & & $2.1 \pm 1.3$ & & $10.1 \pm 2.6$ & & $22.3 \pm 3.9$ & & $54.6 \pm 17.7$ & $<0.001$ \\
\hline BDI score & & $13.3 \pm 4.7$ & & $11.5 \pm 8.7$ & & $12.2 \pm 8.8$ & & $14.5 \pm 10.8$ & 0.43 \\
\hline
\end{tabular}

criteria per reported AHI values from the overnight PSG study: (i) primary snoring group is the control group of the study (AHI $<5$ events/hour), (ii) mild OSA (5 events/hour $\leq$ AHI $<15$ events/hour), (iii) moderate OSA (15 events/hour $\leq$ AHI $<30$ events/ hour) and (iv) severe OSA group (AHI $\geq 30$ events/ hour). ${ }^{[3]}$

\section{Statistical analysis}

Data were analyzed by means of IBM SPSS Statistics version 21.0 for Windows (IBM Corporation, Armonk, NY, USA). Normality of data in each group was tested with Kolmogorov-Smirnov test. Data were shown as mean \pm standard deviation for continuous variables, and number of cases was used for categorical variables. Differences between the groups were analyzed by Kruskal Wallis or chi-square as appropriate. Correlational analyses were calculated according to Spearman rho. The level of significance was set at 0.05 .

\section{RESULTS}

Descriptive statistics of BDI, ESS and sleep lab evaluation according to the groups are given in Table 1 . There was no significant difference between the groups in terms of BMI, ESS score and BDI score $(p=0.13$, $\mathrm{p}=0.8$ and $\mathrm{p}=0.43$, respectively).

Apnea-hypopnea (AHI) was not correlated significantly with the BDI scores $(p=0.26)$. The participants were classified according to BDI cut off values and it was detected that there were 64 participants (61\%) with minimum or no depression, 21 participants (20\%) with mild depression, 13 participants (12.4\%) with moderate depression and seven participants (6.7\%) with severe depression in the study group. Table 2 shows the distribution of the participants with depression according to the groups. Although there was no significant correlation between AHI and BDI score, we found a significant difference between

\begin{tabular}{|c|c|c|c|c|}
\hline \multicolumn{5}{|c|}{$\begin{array}{r}\text { Table } 2 \\
\text { Distribution of participants in terms of prevalence o }\end{array}$} \\
\hline & Primary snoring & Mild OSA & Moderate OSA & Severe OSA \\
\hline & $\mathrm{n}$ & $\mathrm{n}$ & $\mathrm{n}$ & $\mathrm{n}$ \\
\hline Non-existent/minimum depression & 4 & 23 & 23 & 14 \\
\hline Mild depression & 8 & 3 & 3 & 7 \\
\hline Moderate depression & 0 & 5 & 4 & 4 \\
\hline Severe depression & 0 & 2 & 3 & 2 \\
\hline Total (n) & 12 & 33 & 33 & 27 \\
\hline
\end{tabular}




\begin{tabular}{|lccccc|}
\hline \multicolumn{5}{|c|}{ Table 3} \\
Distribution of participants in terms of excessive daytime sleepiness according to the study groups \\
\hline
\end{tabular}

the study groups in terms of prevalence of depression $(p=0.006)$. Mild to moderate depression was found more often in OSA patients than in primary snorers. Also AHI and BDI scores were not correlated with BMI ( $p=0.7, p=0.64)$.

When the ESS scores were evaluated, it was found that 44 participants had a score $>10$, which mean that those were considered to have EDS and the scores of 61 participants were $\leq 10$, mean that EDS was not present in these participants. Table 3 shows the distribution of the participants whether EDS was present or not according to the groups. There was no significant difference between the groups in terms of EDS identification $(p=0.78)$. Also ESS scores were not significantly correlated with AHİ, BDI scores and BMI $(p=0.08, p=0.16$ and $p=0.52$ respectively). In addition, when the participants were classified according to BDI cutoff values, no difference was found between participants with/without EDS in terms of depression severity $(\mathrm{p}=0.81)$ (Table 4$)$.

\section{DISCUSSION}

The current investigation produced four major findings: (i) Apnea-hypopnea index was not significantly correlated with BDI score, ESS score and BMI. (ii) There was a significant difference in study groups in terms of prevalence of depression. Mild to moderate depression was found more often in OSA patients than in primary snorers. (iii) Beck depression inventory score was not correlated significantly with ESS score and
BMI. (iv) There was no significant difference between in study groups in terms of EDS identification.

There is a controversy in the current literature about the correlation between OSA and depression. Macey et al., ${ }^{[25]}$ in a population of 49 people with severe OSA and low comorbidities, found no association between the depressive symptoms assessed with the BDI and OSA severity. Also, Dominici and Gomes, ${ }^{[26]}$ in a study of 123 cases referred to the sleep laboratory, showed a slightly significant association in the univariate analysis between the AHI and BDI scores. This association was no longer significant in the multivariate analysis when other variables were included, such as ESS score, BMI, comorbidity, age, and gender. In addition, Ishman et al., ${ }^{[27]}$ noted that patients with OSA and ESD had more probabilities of showing depressive symptoms, though they did not find a significant association between OSA severity and BDI score, applying both univariate and multivariate analyses.

On the other side, Sharafkhaneh et al. ${ }^{[28]}$ found the high prevalence of depressive disorders in patients with OSA. The National Health and Nutrition Examination Survey 2005-2008 reported sleep apnea and frequent snorting/stopping of breathing were associated with probable major depression. ${ }^{[29]}$ In addition, Chandra et al. ${ }^{[17]}$ found the prevalence of the depression more common in OSA patients than in the normal population.

The low number of female patients and subjective character of ESS and BDI were the main limitation

\begin{tabular}{|c|c|c|c|c|}
\hline Distribution of participants & $\begin{array}{c}\text { Table } 4 \\
\text { ms of excessive daytime s }\end{array}$ & ness accordi & depression & \\
\hline & $\begin{array}{c}\text { Non-existent/minimum } \\
\text { depression }\end{array}$ & $\begin{array}{c}\text { Mild } \\
\text { depression }\end{array}$ & $\begin{array}{l}\text { Moderate } \\
\text { depression }\end{array}$ & $\begin{array}{c}\text { Severe } \\
\text { depression }\end{array}$ \\
\hline & $\mathrm{n}$ & $\mathrm{n}$ & $\mathrm{n}$ & $\mathrm{n}$ \\
\hline Excessive daytime sleepiness present & 39 & 12 & 7 & 3 \\
\hline Not excessive daytime sleepiness & 25 & 9 & 6 & 4 \\
\hline
\end{tabular}


of this study. Also the study design did not clarify the pathophysiological relationships between OSA and depression. Although there was no correlation between AHI and BDI in our study, it did not mean that there is no link between depression and OSA because we also found that mild to moderate depression was more common in OSA patients than primary snorers.

\section{Conclusion}

The current investigation with study groups, matching age, sex, BMI, sleepiness and comorbidities demonstrated that mild to moderate depression was found more often in OSA patients than in primary snorers, although AHI was not correlated with BDI.

\section{Declaration of conflicting interests}

The authors declared no conflicts of interest with respect to the authorship and/or publication of this article.

\section{Funding}

The authors received no financial support for the research and/or authorship of this article.

\section{REFERENCES}

1. Young T, Palta M, Dempsey J, Skatrud J,Weber S, Badr S. The occurrence of sleep-disordered breathing among middle-aged adults. N Engl J Med 1993;328:1230-5.

2. Young T, Finn L, Peppard PE, Szklo-Coxe M, Austin D, Nieto FJ, et al. Sleep disordered breathing and mortality: eighteen-year follow-up of the Wisconsin sleep cohort. Sleep 2008;31:1071-8.

3. Epstein LJ, Kristo D, Strollo PJ Jr, Friedman N, Malhotra A, Patil SP, et al. Adult Obstructive Sleep Apnea Task Force of the American Academy of Sleep Medicine. Clinical guideline for the evaluation, management and long-term care of obstructive sleep apnea in adults. J Clin Sleep Med 2009;15;5:263-76.

4. Young T, Peppard PE, Gottlieb DJ. Epidemiology of obstructive sleep apnea: a population health perspective. Am J Respir Crit Care Med 2002;165:1217-39.

5. ChamiHA, ResnickHE, Quan SF, Gottlieb DJ.Association of incident cardiovascular disease with progression of sleep disordered breathing. Circulation 2011;123:1280-6.

6. Redline S, Yenokyan G, Gottlieb DJ, Shahar E, O'Connor GT, Resnick HE, et al. Obstructive sleep apnea-hypopnea and incident stroke: the sleep heart health study. Am J Respir Crit Care Med 2010;182:269-77.

7. McCall WV, Harding D, O'Donovan C. Correlates of depressive symptoms in patients with obstructive sleep apnea. J. Clin. Sleep Med. 2006;2:424-6.

8. Salorio CF, White DA, Piccirillo J, Duntley SP, Uhles ML. Learning, memory, and executive control in individuals with obstructive sleep apnea syndrome. J Clin Exp Neuropsychol 2002:24:93-100.

9. Beebe DW, Gozal D. Obstructive sleep apnea and the prefrontal cortex: towards a comprehensive model linking nocturnal upper airway obstruction to daytime cognitive and behavioral deficits. J Sleep Res 2002;11:1-16.

10. Verstraeten E. Neurocognitive effects of obstructive sleep apnea syndrome. Curr Neurol Neurosci Rep 2007;72:161-6.

11. Saunamaki T, Jehkonen M. Depression and anxiety in obstructive sleep apnea syndrome: a review. Acta Neurol Scand 2007;116:277-88.

12. Ejaz SM, Khawaja IS, Bhatia S, Hurwitz TD. Obstructive sleep apnea and depression: a review. Innov Clin Neurosci 2011;8:17-25.

13. Jackson ML, Stough C, Howard ME, Spong J, Downey LA, Thompson B. The contribution of fatigue and sleepiness to depression in patients attending the sleep laboratory for evaluation of obstructive sleep apnea. Sleep Breath 2011;15:439-45.

14. Ohayon MM. Epidemiology of depression and its treatment in the general population. J Psychiatr Res 2007;41:207-13.

15. Harris M, Glozier N, Ratnavadivel R, Grunstein RR. Obstructive sleep apnea and depression. Sleep Med Rev 2009;13:437-44.

16. Aloia MS, Arnedt JT, Smith L, Skrekas J, Stanchina M, Millman RP. Examining the construct of depression in obstructive sleep apnea syndrome. Sleep Med 2005;6:115-1.

17. Chandra RK, Epstein VA, Fishman AJ. Prevalence of depression and antidepressant use in an otolaryngology patient population. Otolaryngol Head Neck Surg 2009;141:136-8.

18. Asghari A, Mohammadi F, Kamrava SK, Tavakoli S, Farhadi M. Severity of depression and anxiety in obstructive sleep apnea syndrome. Eur Arch Otorhinolaryngol 2012;269:2549-53.

19. Rey de Castro J, Rosales-Mayor E. Depressive symptoms in patients with obstructive sleep apnea/hypopnea syndrome. Sleep Breath 2013;17:615-20.

20. Johns MW. A new method for measuring daytime sleepiness: the Epworth sleepiness scale. Sleep 1991;14:540-5.

21. Izci B, Ardic S, Firat H, Sahin A, Altinors M, Karacan I. Reliability and validity studies of the Turkish version of the Epworth Sleepiness Scale. Sleep Breath 2008;12:161-8.

22. Kapci EG, Uslu R, Turkcapar H, Karaoglan A. Beck Depression Inventory II: evaluation of the psychometric properties and cut-off points in a Turkish adult population. Depress Anxiety 2008;25:104-10.

23. Beck AT, Steer RA, Brown GK. BDI-II Manual. San Antonio, TX: The Psychological Corporation; 1996.

24. Kushida CA, Littner MR, Morgenthaler T, Alessi CA, Bailey D, Coleman J Jr, et al. Practice parameters for the indications for polysomnography and related procedures: an update for 2005. Sleep 2005;28:499-521.

25. Macey PM, Woo MA, Kumar R, Cross RL, Harper RM. Relationship between obstructive sleep apnea severity and sleep, depression and anxiety symptoms in newly-diagnosed patients. PLoS One 2010;5:e10211.

26. Dominici M, Gomes Mda M. Obstructive sleep apnea (OSA) and depressive symptoms. Arq Neuropsiquiatr 2009;67:35-9.

27. Ishman SL, Cavey RM, Mettel TL, Gourin CG. Depression, sleepiness, and disease severity in patients with 
obstructive sleep apnea. Laryngoscope 2010;120:2331-5.

28. Sharafkhaneh A, Giray N, Richardson P, Young T, Hirshkowitz M. Association of Psychiatric Disorders and Sleep Apnea in a Large Cohort. Sleep 2005;28:1405-11.
29. Wheaton AG, Perry GS, Chapman DP, Croft J. Sleep disordered breathing and depression among U.S. adults: National Health and Nutrition Examination Survey, 20052008. Sleep 2012;35:461-7. 